\title{
Retorika Digital dan Social Network Analysis Generasi Milenial Tionghoa melalui YouTube
}

\author{
Sinta Paramita dan Lydia Irena \\ Prodi Ilmu Komunikasi Fakultas Ilmu Komunikasi Universitas Tarumanagara \\ Jalan. Letjen S. Parman, no: 1 Lantai 11 Gedung Utama Jakarta Barat \\ sintap@fikom.untar.ac.id, lydiai@fikom.untar.ac.id
}

Masuk tanggal : 28-03-2020, revisi tanggal : 31-05-2020, diterima untuk diterbitkan tanggal : 09-06-2020

\begin{abstract}
The millennial generation of ethnic Chinese is a native digital generation that contributes to technological development, with strong skills and understanding in communicating creative messages through technology, the Chinese millennial generation also contributed to the development of Indonesia's digital culture. Technological developments have resulted in new jobs such as YouTube. YouTuber is someone who creates interesting audiovisual content so that the audience is interested and makes the content as entertainment or certain recommendations. By using the theory of rhetoric put forward by Aristotle, this study will look at the crowds of information flow in one content and see the strength of content as what was created to attract the attention of the audience, by using a quantitative approach through the Social Network Analysis (SNA) method. This study aims to describe the complexity of network communication in content and find out the digital rhetoric of the Chinese millennial generation that is currently developing in creating digital content. The results of the analysis show a high centralized value approaching 1 , the results obtained in this study 0.052 indicate there is an account that dominates the information in the content. A density value of 0 indicates that there are no closely related accounts in the content. Reciprocity or reciprocal values 0 indicate that there is no two-way communication. The modularity or community values in the group 0.763 indicate that in the content there is a split network that cones to a certain account. The value of the diameter or the longest distance between network accounts reaches number 4, content with the power of deliberative rhetoric is proven to be able to attract the attention of the audience
\end{abstract}

Keywords: chinese millennial generation, digital rhetoric, social network analysis

\begin{abstract}
Abstrak
Generasi milenial etnis Tionghoa adalah generasi native digital yang turut berkontribusi pada perkembangan teknologi, dengan kecakapan dan pemahaman yang kuat dalam mengkomunikasikan pesan-pesan kreatif melalui teknologi, generasi milenial Tionghoa pun berkontribusi pada pengembangan budaya digital Indonesia. Perkembangan teknologi telah menghasilkan pekerjaan baru salah satunya seperti YouTuber. YouTuber adalah seseorang yang menciptakan konten audio visual menarik sehingga khalayak tertarik dan menjadikan konten tersebut sebagai hiburan atau rekomendasi tertentu. Penelitian menggunakan teori retorika yang dikemukakan oleh Aristoteles, penelitian ini akan melihat keramaian arus informasi dalam satu konten dan melihat kekuatan konten seperti apa yang diciptakan untuk menarik perhatian khalayak, dengan menggunakan pendekatan kuantitatif melalui metode Social Netwok Analysis (SNA). Penelitian ini bertujuan untuk menjabarkan kompleksitas komunikasi jaringan dalam sebuah konten dan mengetahui retorika digital
\end{abstract}


generasi milenial Tionghoa yang berkembang saat ini dalam membuat konten digital. Hasil analisis menunjukkan nilai sentralisasi tinggi mendekati 1 , hasil yang diperoleh dalam penelitian ini 0.052 menunjukkan terdapat akun yang mendominasi informasi dalam konten tersebut. Nilai density atau kepadatan 0 menunjukkan tidak ada akun yang terhubung secara erat dalam konten tersebut. Nilai reciprocity atau timbal balik 0 menunjukkan tidak ada yang menunjukkan komunikasi dua arah. Nilai modulitas atau komunitas di dalam kelompok 0.763 menunjukkan bahwa di dalam konten tersebut terjadi perpecahan jaringan yang mengerucut kepada akun akun tertentu. Nilai diameter atau jarak terpanjang antara akun jaringan mencapai angka 4 , konten dengan kekuatan retorika deliberative terbukti dapat menarik perhatian khalayak.

Kata Kunci: generasi milenial Tionghoa, retorika digital, social netwok analysis

\section{Pendahuluan}

Saat ini generasi milenial merupakan kekuatan besar dalam menggerakkan roda perekonomian suatu bangsa melalui teknologi. Data menurut Jeffrey Sachs Center mencatat, bahwa lebih dari setengah penduduk ASEAN yang berjumlah 629 juta orang berusia di bawah 30 tahun, di mana 90 persennya berusia 15-24 tahun yang familier terhadap internet dan dunia digital (Prasetiantono, 2018). Catatan tersebut sejalan dengan perkembangan pemanfaatan teknologi di Indonesia. Asosiasi Penyelenggara Jasa Internet Indonesia APJII 2017 memaparkan bahwa total populasi penduduk Indonesia 262 Juta orang, sebanyak 143.26 Juta jiwa atau $54.8 \%$ adalah pengguna internet dan berdasarkan usia menunjukkan pengguna internet di Indonesia didominasi oleh generasi muda 49.52\% yang berumur 19-34 Tahun. Dan penetrasi pengguna internet didominasi oleh usia 13-18 tahun atau 75.50\% (APJII, 2017).

Pertumbuhan generasi milenial sejalan dengan perkembangan teknologi komunikasi dan informasi yang membawa percepatan pembangunan suatu bangsa di berbagai sektor, salah satunya adalah sektor ekonomi. Dalam perkembangan revolusi industri 4.0, teknologi berbasis internet memengaruhui perkembangan berbagai pelayanan diberbagai sector (Prabowo \& Irwansyah, 2018). Secara cepat teknologi dapat mengubah komunikasi antar manusia dari konvensional menjadi digital. Komunikasi digital merupakan komunikasi melalui perangkat digital yang terhubung dalam satu jaringan internet. Keunggulan komunikasi digital adalah memudahkan manusia untuk berkomunikasi tanpa dibatasi tempat dan waktu. Kapan saja dan dimana saja transfer informasi dapat dengan mudah diproduksi, diproses, dan disebarluaskan. Keunggulan komunikasi digital banyak dimanfaatkan masyarakat untuk berbisnis, khususnya kaum muda. Kelahiran media sosial memudahkan interaksi sosial yang juga dapat bersifat dua arah (Saleh \& Pitriani, 2018). Saat ini dapat dengan mudah ditemui generasi milenial yang menggeluti $e$ commerce, start-up, online shopping, dan lain-lain. Munculnya pekerjaan baru yang memanfaatkan jaringan internet mulai menjamur. Misalnya saja pekerjaan baru yang memanfaatkan media sosial seperti Influencer, blogger, YouTuber, endorser instagram, vlogger, gamers menjadi ladang generasi milenial untuk mendapatkan uang. Salah satu yang diangkat dalam penelitian ini sebagai subjek penelitian dalah YouTube. 
Menurut GetCRAFT, firma pemasaran berbasis di Asia Tenggara, dalam laporannya bertajuk "Indonesia Native Advertising and Influencer Marketing Report 2018" memetakan industri digital di Indonesia (GetCRAFT, 2018). Tercatat bahwa masyarakat Indonesia lebih banyak mengonsumsi internet melalui desktop dan tablet selama 8 jam 44 menit, sedangkan 3 jam 55 menit masyarakat Indonesia menikmati internet dari mobile phone. Selain itu dalam konsumsi media sosial lebih banyak mencapai 3 jam 16 menit dibandingkan TV diangkat 2 jam 23 menit. Dari sisi penggunaan media sosial perusahaan dapat beriklan melalui saluran resmi alias berhubungan langsung dengan pemilik platform. Gambar 1 di bawah ini adalah hasil pemetaan yang industry digital di Indonesia oleh GetCRAFT.

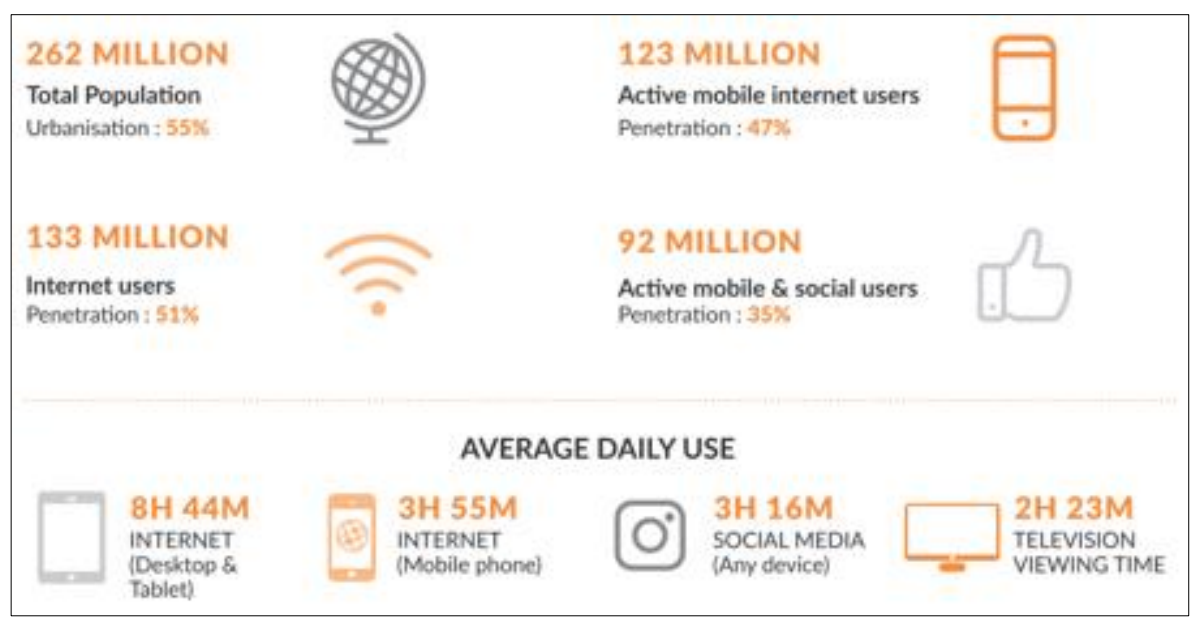

Gambar 1: Industri Digital di Indonesia. (Sumber: GetCRAFT, 2018)

Salah satu fenomena yang kini muncul adalah beriklan di media sosial melalui influencer salah satunya adalah YouTube. Pemasaran melalui influencer, dalam laporan Forbes adalah mengkapitalisasi jangkauan media sosial dengan membayar selebritas di internet dengan tingkat ketenaran yang bervariasi untuk diunggah di akun media sosial mereka guna menjangkau para pengikut setia (Zaenudin, 2018) Influencer bisa dikatakan sebagai saluran komunikasi pemasaran jenis baru. Influencer adalah selebriti internet yang akun di media sosialnya dibayar untuk mengunggah produk-produk tertentu. Orang yang memberikan rekomendasi online berupa ulasan tentang produk atau pengalaman setelah menggunakan produk disebut influencer (Moriansyah, 2015). Lebih lanjut Taylor mengatakan peer influence berperan untuk meningkatkan hubungan interpersonal merupakan tujuan dari media sosial. Media sosial terdiri dari hubungan antar individu yang menjadi suatu jejaring yang berhubungan dengan cara saling bertukar informasi dan melakukan komunikasi antar individu atau didalam grup akan membuat antar individu atau grup menjadi lebih dekat (Moriansyah, 2015). Peer communication dapat mempengaruhi sikap dan perilaku terhadap produk atau brand. Dalam media sosial pengguna yang rekomendasinya sering atau dipercaya oleh pengguna media sosial yang lain disebut influencer atau opinion leader. Para pemasar dapat menggunakan peran para opinion leader untuk melakukan komunikasi pemasaran 
kepada target konsumen, karena rekomendasi dari mereka lebih dipercaya dan dapat mempengaruhi jejaringnya atau peer influence (Moriansyah, 2015).

Salah satu generasi yang juga meramaikan teknologi komunikasi disektor ekonomi adalah generasi milenial Tionghoa. Berdasarkan data penduduk Badan Pusat Statistik 2010, masyarakat Etnis Tionghoa di Indonesia mencapai 2.83 Juta jiwa atau 1.2 persen dari total penduduk Indonesia yang berjumlah 236.73 juta jiwa. Etnis Tionghoa di Indonesia masuk ke dalam 20 besar etnis terbanyak di Indonesia. Namun catatan sejarah menuliskan bahwa etnis Tionghoa pernah mengalami masa kegelapan terkait konflik dan diskriminasi yang membuat etnis Tionghoa semakin teralienasi. Berdasarkan penelitian terdahulu, daerah yang menjadi pusat konflik dan diskriminasi yang dialami masyarakat Etnis Tionghoa terparah berada di Jakarta, Medan, dan Solo (Pelly, 2018). Namun, saat ini interaksi masyarakat Etnis Tionghoa di masyarakat semakin membaik. Pemerintah menjamin kebebasan dan melindungi seluruh Etnis di Indonesia dalam menciptakan keharmonisan dan keberagaman di Indonesia. Generasi milenial Tionghoa saat ini adalah generasi yang bisa dikatakan tidak secara langsung menerima sejarah kelam diskriminasi Etnis Tionghoa pada masa lalu. Generasi milenial Tionghoa saat ini juga merupakan generasi yang tumbuh dengan perkembangan teknologi komunikasi. Kemahiran dan pemahaman yang kuat untuk mengkomunikasi pesan kreatif melalui teknologi, generasi milenial Tionghoa memberikan kontribusi bagi perkembangan budaya digital Indonesia.

Dua puluh tahun lebih sudah berlalu dari 1998 diskriminasi yang dialami oleh generasi etnis Tionghoa. Saat ini generasi terbaru etnis Tionghoa adalah generasi milenial yang merupakan generasi native digital. Gasser dan Palfrey menyimpulkan generasi native digital adalah generasi yang mahir dalam menggunakan media baru, sedangkan Don Tapscott menyebut generasi itu adalah generasi internet. Generasi native digital, generasi internet merupakan rujukan pemikiran besar yang mengarah kepada terbentuknya generasi milenial. Lebih lanjut (Tapscott, 2013) memaparkan terdapat delapan norma yang dimiliki generasi milenial, yaitu:

a. Kebebasan, generasi milenial menginginkan kebebasan dalam segala hal yang mereka perbuat, dari kebebasan memilih hingga kebebasan berekspresi.

b. Kustomisasi, generasi milenial senang membuat sesuatu sesuai dengan selera (kustomisasi dan personalisasi).

c. Penyelidikan, generasi milenial senang melakukan penyelidikan terhadap barang-barang dalam bisnis online. Penyelidikan bisa berupa perbandingan barang, memberikan ulasan dan lain-lain.

d. Integritas, generasi milenial mencari integritas korporasi dan keterbukaan sewaktu mereka memutuskan yang akan mereka beli atau di mana mereka akan bekerja.

e. Kolaborasi, generasi milenial mengandalkan kolaborasi dan relasi bisa melalui media sosial atau berbagai saluran dalam media baru.

f. Hiburan, generasi milenial ingin hiburan dan kegiatan bermain tetap ada dalam pekerjaan, pendidikan, dan kehidupan sosial mereka.

g. Kecepatan, generasi milenial membutuhkan kecepatan dalam berselancar dalam media baru. Tidak hanya dalam video game. 
Sinta Paramita dan Lydia Irena: Retorika Digital dan Social Network Analysis Generasi Milenial Tionghoa melalui YouTube

h. Inovasi, generasi milenial merupakan para inovator dengan mencari cara-cara inovatif untuk berkolaborasi, menghibur diri, belajar, dan bekerja sama.

Penelitian yang dilakukan Faisal dalam memahami tren generasi milenial kedalam beberapa klasifikasi tahun kelahiran dari sebuah generasi melukiskan bahwa generasi baby boomers (lahir antara dekade 1940 hingga 1960-an), generasi Gen X (lahir antara dekade 1970 hingga 1980-an), Generasi milenial (lahir antara dekade 1980 hingga 2000-an). Lebih lanjut Faisal berkesimpulan identitas dari generasi milenial memiliki 5 (lima) aspek (Faisal, 2018):

1. Generasi milenial memiliki sifat komunal, atau tidak bisa hidup sendiri, dia selalu berkerumun dalam suatu lingkungan.

2. Generasi milenial Indonesia cenderung menyukai kesederhanaan.

3. Generasi milenial memiliki naive personality, naif yang dimaksud adalah dalam pertemanan generasi milenial saling menghargai nilai-nilai, seperti ketulusan dan kesetiaan.

4. Generasi milenial into values atau hal yang sifatnya kearifan dan religious wisdom. Bisa dilihat dari hasil unggahan di media sosial yang menggunakan kutipan kata-kata bijak tokoh-tokoh sejarah.

5. Generasi milenial family matters, salah satu poin penting dari anak muda Indonesia adalah kekeluargaan yang sangat dipegang kuat.

Generasi milenial Tionghoa dilihat dari tahun kelahiran antara dekade 1980 hingga 1990-an, memiliki karakter yang serupa dengan generasi milenial pada umumnya. Namun budaya dalam ruang sosial generasi tersebut dapat memberikan warna tersendiri dalam memanfaatkan media baru salah satunya pengembangan bisnis digital melalui konten-konten sosial media.

\section{Retorika Digital}

Kehadiran retorika dalam kehidupan bermasyarakat dan berbudaya ini, bisa juga dilihat dari segi pandangan terhadap kehidupan itu sebagai rangkaian persoalan dan penyelesaian, seperti yang dikemukakan oleh seorang ahli retorika kenamaan, Donald C. Bryant. Menurut Bryant kehidupan bersama atau bermasyarakat ini penuh dengan masalah yang taut-bertaut satu sama lainnya. Masalah-masalah inilah yang membuat masyarakat itu dinamis dalam pertumbuhan dan perkembangannya (Budiman, 2018). Dalam kajian ilmu komunikasi, retorika hadir sebagai tradisi dalam ilmu komunikasi. Teori retorika memusatkan perhatian pada retorika, yang Aristoteles tekankan memiliki tujuan persuasi. Seorang pembicara yang tertarik untuk memersuasi audiens harus mempertimbangkan tiga bukti retorika: logika (logos), emosi (pathos), dan etika atau kredibilitas (ethos) (Richard \& Turner, 2017).

Lebih lanjut logika (logos) merupakan bentuk penggunaan argumentasi dan bukti dalam pidato. Seorang komunikator yang baik akan berbicara dengan menggunakan bukti atau fakta, sehingga audiens dapat dengan mudah tertarik dan percaya dengan apa yang disampaikan. Emosi (pathos) merupakan bukti emosional yang didapat dari anggota audiens. Audiens akan terbawa emosinya ketika melihat dan mendengar komunikator yang pandai melibatkan pesan emosional kepada 
audiens. Audiens akan merasa bahwa komunikator tersebut memiliki kredibilitas karena pesan yang disampaikan. Karakter (ethos) merupakan pandangan mengenai karakter, inteligensia, dan niat baik seorang pembicara. Komunikator tidak hanya berbicara pengalaman kepada audiens tetapi juga memperhitungkan relasi antara komunikator dan audiens dengan melibatkan rasa percaya berdasarkan relasi.

Kehidupan kontemporer memberikan masyarakat kesempatan untuk berbicara di depan orang banyak. Politisi, pemimpin spiritual, dan lain-lain adalah orang yang menghabiskan waktunya untuk berbicara dengan orang lain, baik formal maupun informal. Bagi warga Amerika Serikat berbicara di depan umum merupakan hal yang penting (Richard \& Turner, 2017). Teknik berbicara di depan umum bisa dikatakan sebagai retorika. Lebih lanjut Aristoteles menekankan retorika merupakan ilmu yang menekankan persuasi untuk menarik perhatian khalayak (Richard \& Turner, 2017). Saat ini dengan perkembangan teknologi komunikasi dan informasi saat ini yang memudahkan siapa pun untuk berkomunikasi tanpa harus di mimbar umum. Hal ini menjadi menarik untuk diteliti, ketika generasi milenial Tionghoa dengan sejarah yang dialami bergerak maju untuk mengembankan bisnis digital melalui teknologi.

Aristoteles menawarkan lima prinsip yang disebut sebagai kanon-kanon dalam retorika yakni penciptaan, pengaturan, gaya, penyampaian, dan ingatan. Teori Retorika mencakup pemikiran yang sangat luas dalam bidang komunikasi, berikut adalah asumsi-asumsi yang menuntun teori ini untuk berkembang. Pertama, pembicara yang efektif harus mempertimbangkan khalayak mereka. Kedua, pembicara yang efektif menggunakan beberapa bukti dalam presentasi mereka. Komunikasi merupakan proses transaksional, pembicara tidak diperkenankan merangkai pidato tanpa memikirkan pendengar atau khalayak mereka. Kemudian pidato yang mereka buat harus memiliki bukti retoris yang sudah dijelaskan sebelumnya yaitu ethos, pathos, dan logos.

Retorika dibagi ke dalam tiga bagian. Pertama, retorika forensik (forensic rhetoric) tipe ini mengacu pada cara pembicara membimbing audiens untuk merasa bersalah atau tidak bersalah. Kedua retorika epideiktik (epideictic rhetoric) tipe ini mengacu pada pujian atau penyalahan. Ketiga adalah retorika deliberatif (deliberative rhetoric) tipe ini mengacu pada penentuan aksi audien (Richard \& Turner, 2017).

Dalam teori retorika, komunikator seperti pembicara, produser media, dan penulis melihat masalah atau tantangan sebagai kebutuhan yang harus dihadapi dengan pesan yang disusun sedemikian rupa. Komunikator membangun strategi dan sering menggunakan pendekatan yang umum untuk menggerakkan khalayak. Teori ini memahami bahwa kata-kata memiliki kekuatan, informasi itu berguna dalam membentuk penilaian, dan komunikasi dapat dievaluasi dan dikembangkan. Menantang pandangan lain yang menyatakan bahwa kata-kata bukanlah aksi, apa yang ditampilkan bukanlah kenyataan, gaya bukanlah substansi, dan opini bukanlah kenyataan (Littlejohn, 2002). Dari pemaparan diatas, dapat digambarkan bahwa retorika digital seperti pada gambar 2 di bawah ini. Gambar 2 di bawah ini sekaligus menjadi kerangka pemikiran dalam melihat konten digital YouTuber. 


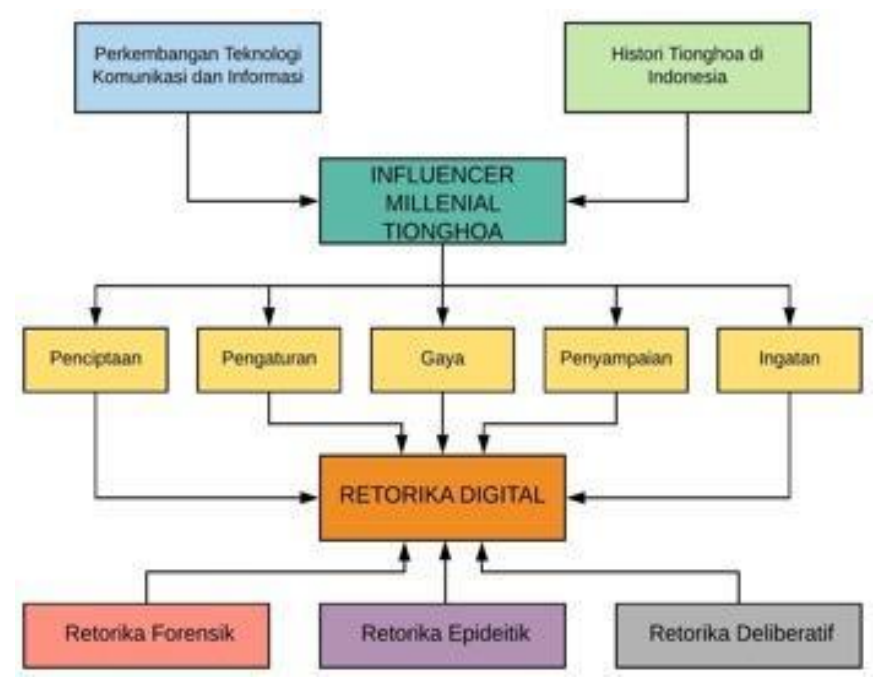

Gambar 2: Retorika Digital (Sumber: Peneliti)

\section{Social Netwok Analysis}

Social Netwok Analysis (SNA) merupakan alat analisis untuk mengidentifikasi struktur sosial dan menjelaskan masing-masing aktor yang terlibat di dalam struktur sosial tersebut. Kata kunci dalam penggunaan SNA adalah penyebaran informasi yang memiliki efek dalam jaringan sosial. Menurut Sapountzi dan Psannis SNA merupakan permodelan yang dilambangkan dengan titik nodes dan interaksi antar pengguna yang dilambangkan dengan garis edges. Hal ini dibutuhkan untuk memahami pengguna di dalam sebuah pola interaksi sosial (Bratawisnu \& Alamsyah, 2018). Berkembangnya SNA sebagai alat analisis biasa digunakan dalam bidang ilmu sistem informasi dan teknologi. Sebagai contoh adalah penelitian terkait penerapan SNA dalam organisasi, penelitian mendeskripsikan pola komunikasi di dalam interaksi kelompok sosial di dalam sebuah perusahaan (Dendy, Iriani, \& Manongga, 2020). Salah satu penelitian lain terkait SNA adalah pengembangan SNA dalam analisis wacana dalam konteks komunikasi. Penerapan discourse networking analysis sebagai bentuk perkembangan metodologis dalam sosial. Penelitian ini memberikan pengetahuan baru terkait perkembangan metodologis saat ini (Pratama \& Ulfa, 2017).

Saat ini pemanfaatan SNA sudah menjadi bagian alat analisis dari berbagai multidisipliner ilmu. Seiring dengan berkembangnya teknologi komunikasi dan informasi saat ini, SNA juga mulai ramai dimanfaatkan bidang ilmu komunikasi untuk mengetahui pola atau interaksi berupa teks yang terjadi dalam ruang digital. SNA biasanya digunakan sebagai metode yang dapat memberikan ilustrasi visualisasi hubungan dalam jaringan dengan tanda aktor atau node dan links sebagai relasi atau hubungan antar aktor (Eriyanto, 2014). Lebih lanjut Iriani memaparkan Metode SNA juga mampu menganalisis dan memetakan pola tersembunyi yang ada dalam interaksi, merupakan metode yang tepat dalam rangka menganalisis arus informasi serta hubungan dalam jaringan (Latupeirissa, Sediyono, \& Iriani, 2019). SNA memiliki property jaringan yang digunakan untuk memetakan hubungan antar user. Adapun beberapa properti jaringan pada SNA antara lain menurut (Bratawisnu \& Alamsyah, 2018): 
1. Nodes merepresentasikan posisi yang dimiliki oleh aktor atau pengguna yang berada dalam dalam sebuah jaringan.

2. Edges mengambarkan hubungan antar aktor atau pengguna yang berada dalam dalam sebuah jaringan.

3. Average degree merupakan jumlah hubungan atau timbal balik pada satu node atau titik dibagi jumlah hubungan atau timbal balik yang terjadi pada satu jaringan sosial.

4. Diameter merupakan jarak terjauh antara dua node yang berdekatan.

5. Average Path Length merupakan rata-rata jarak geodesi, atau rata-rata jalur yang dilewati oleh tiap node ke node lainnya.

Hanneman \& Riddle menambahkan di dalam SNA yang perlu diperhatikan adalah ukuran dari node atau node size. Ukuran node dapat dilihat dari dua kategori yaitu derajat masuk indegree dan derajat keluar outdegree. Indegree merupakan sebuah node yang memiliki banyak garis yang masuk dalam node. Hal tersebut menunjukkan popularitas dari sebuah node yang selalu memproduksi informasi dan menerima informasi. Sedangkan outdegree merupakan node yang memiliki jumlah garis yang keluar dari sebuah node (Netlytic, 2020). Definisi lain terkait indegree adalah jumlah link yang mengarah kepada aktor dan outdegree adalah jumlah link yang keluar dari aktor (Eriyanto, 2014). Dari kedua penjelasan di atas dapat disederhanakan kembali bahwa indigree sebagai sebuah aktor atau akun yang menyebarkan informasi mendapatkan respon dari informasi tersebut. Sedangkan outdegree merupakan aktivitas memberikan respon yang diberikan pengguna kepada akun tertentu, misalnya konten yang dibuat pada YouTube mendapat berbagai macam tanggapan yang ditujukan kepada konten tersebut oleh para pengguna. Sehingga dalam sistem SNA akan terlihat garis penghubung yang merujuk kepada satu akun. Sedangkan outdegree merupakan user.

Mengetahui derajat masuk dan keluar dalam sistem jaringan sanggatlah penting dalam analisis SNA. Hal tersebut menunjukkan adanya pemain kunci atau akun yang berperan besar dalam mengendalikan komunikasi dalam sebuah jaringan. Dari sini dapat melihat dominasi akun yang menjadi derajat masuk dan keluar dalam sebuah jaringan.

Dari pemaparan pendahuluan di atas maka tujuan dari penelitian ini adalah pertama untuk mengetahui interaksi atau arus informasi dalam satu konten YouTube dan untuk mengetahui kekuatan konten seperti apa yang diciptakan untuk menarik perhatian khalayak. Dengan menggunakan aplikasi SNA untuk interaksi khalayak serta pemetaan retorika digital terhadap konten YouTube. Penelitian ini diharapkan dapat memberikan kontribusi pemikiran baru dalam pemanfaatan SNA dan terkait tradisi ilmu komunikasi retorika yang memusatkan perhatian pada tujuan persuasi pada era perkembangan teknologi komunikasi dan informasi saat ini. 
Sinta Paramita dan Lydia Irena: Retorika Digital dan Social Network Analysis Generasi Milenial Tionghoa melalui YouTube

\section{Metode Penelitian}

Pendekatan penelitian yang digunakan dalam penelitian ini adalah pendekatan kuantitatif untuk mengetahui hubungan antara aktor atau node di dalam konten YouTube melalui aplikasi SNA dan mengetahui bagaimana bentuk retorika digital influencer milenial Tionghoa. Subjek dari penelitian ini adalah akun media sosial influencer Milenial Tionghoa. Objek penelitian yang digunakan dalam penelitian ini adalah akun Nessie Judge seorang YouTuber yang memiliki lebih dari 1 juta follower dan konten yang diciptakan mengarah pada pengembangan ekonomi kreatif. Teknik pengumpulan data dalam penelitian ini adalah menggunakan konten YouTube yang diciptakan oleh kedua YouTuber di atas. Pemilihan konten diambil secara random. Teknik analisis data dalam penelitian ini adalah sebagai berikut:

1. Melakukan random pemilihan konten yang dibuat oleh kedua YouTuber.

2. Koten tersebut dianalisis dengan menggunakan aplikasi social netwok analysis berupa Netlytic yang dapat dilihat pada link ini: https://netlytic.org/home/ .Netlytic digunakan untuk menemukan jaringan komunikasi di antara anggora masyarakat khususnya yang terkoneksi dalam jaringan (Gruzd \& Haythornthwaite, 2013).

3. Di dalam aplikasi Netlytic, peneliti mengunggah konten YouTube dan membuat dua klasifikasi data yaitu name network/who mentions whom, bagian ini merupakan jaringan komunikasi yang dibangun untuk masing-masing konten YouTube untuk menemukan keterkaitan konten dengan audiens. Kedua adalah chain network /who replies to whom, bagian ini disebut jaringan rantai melihat pergerakan audiens berinteraksi dengan audien lain berdasarkan unggahan audiens pada akun YouTube tersebut. Alat ukur yang digunakan dalam kedua kategori tersebut adalah sebagai berikut berdasarkan pemaparan (Netlytic, 2020):

1) Centralization, sentralisasi mengukur tingkat rata-rata sentralitas semua node dalam suatu jaringan. Ketika sebuah jaringan memiliki nilai sentralisasi tinggi mendekati 1 , itu menunjukkan ada beberapa peserta sentral yang mendominasi aliran informasi dalam jaringan.

2) Density adalah kepadatan adalah proporsi dari ikatan yang ada dengan jumlah total ikatan yang mungkin dalam jaringan. Dengan kata lain, dihitung dengan membagi jumlah ikatan yang ada (koneksi) dengan jumlah ikatan yang mungkin. Ukuran ini membantu menggambarkan seberapa dekat peserta dalam suatu jaringan. Ukuran kepadatan ini melengkapi diameter, karena keduanya menilai kecepatan aliran informasi. Semakin dekat pengukuran ini dengan nilai 1, maka akan semakin erat hubungan atau percakapan yang menunjukan peserta dengan berbicara banyak kepada orang lain. Disisi lain jika nilainya 0 , makan menunjukkan hampir tidak ada hubungan dengan orang lain dalam sebuah jaringan. 
3) Reciprocity adalah timbal balik adalah proporsi ikatan yang menunjukkan komunikasi dua arah (juga disebut ikatan timbal balik) dalam kaitannya dengan jumlah total ikatan yang ada. Ini diukur dengan jumlah ikatan timbal balik dalam kaitannya dengan jumlah total ikatan dalam jaringan (tidak semua ikatan mungkin). Nilai yang lebih tinggi menunjukan banyak peserta memiliki percakapan dua arah. Sedangkan nilai rendah menunjukan banyak percakapan satu sisi, sehingga hanya sedikt percakapan dua arah.

4) Modularity adalah modularitas adalah kelompok node yang terhubung erat yang lebih mungkin untuk berkomunikasi satu sama lain dari pada node di luar kluster. Modularitas, membantu menentukan apakah kluster yang ditemukan mewakili komunitas yang berbeda dalam jaringan. Nilai modularitas yang lebih tinggi menunjukkan perpecahan yang jelas antara komunitas yang diwakili oleh kluster di Netlytic. Nilai modularitas yang rendah, biasanya kurang dari 0,5 , menunjukkan bahwa kluster, yang ditemukan oleh Netlytic, akan tumpang tindih lebih banyak, jaringan lebih cenderung terdiri dari kelompok inti node.

5) Diameter adalah menghitung jarak terpanjang antara dua peserta jaringan. Ukuran ini menunjukan ukuran jaringan dengan menghitung jumlah node yang diperlukan untuk perpindahan dari satu sisi ke sisi lain.

4. Mendeskripsikan indegree dan outdegree dalam jaringan konten YouTube.

5. Setelah terinput peneliti akan memaparkan secara visual data social netwok analysis YouTube dari masing-masing objek penelitian.

\section{Hasil Penemuan dan Diskusi}

\section{Social Netwok Analysis (SNA) YouTube Nessie Judge}

Berikut ini adalah data konten yang dianalisis:

Tabel 1: Keterangan konten Nessie Judge

\begin{tabular}{lll}
\hline Akun & $:$ https://www.YouTube.com/user/NessieJudge \\
Konten & $:$ & Annoying Questions Pas Lebaran! \\
Link & $:$ & https://youtu.be/wb5vC9gkW78 \\
Publish & $:$ & 5 Juli 2016 \\
Viewer & $: 117496$ \\
Komen & $:$ & 408
\end{tabular}

Hasil Social Netwok Analysis (SNA) YouTube Nessie Judge menangkap terdapat 2.500 pesan yang terjadi di YouTube dalam membicarakan konten tersebut. Aplikasi Netlytic membagi data pembicaraan tersebut dalam kolom link, waktu, nama akun, dan judul pembicaraan. Dari data di atas peneliti akan mengolahnya dalam dua klasifikasi yaitu name network/who mentions whom dan 
Sinta Paramita dan Lydia Irena: Retorika Digital dan Social Network Analysis Generasi Milenial Tionghoa melalui YouTube

chain network /who replies to whom. Berdasarkan data chain network /who replies to whom, konten Annoying Questions Pas Lebaran! Memiliki respon yang cukup padat yang dapat dilihat pada gambar di bawah ini:

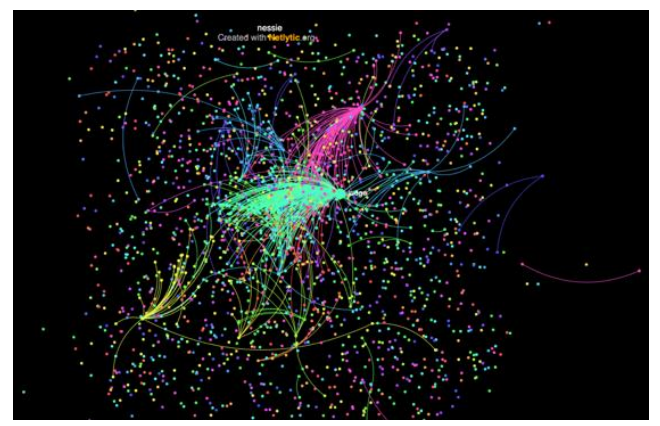

Gambar 3: Data Chain Network (Sumber: Data peneliti)

Warna hijau tosca pada gambar di atas adalah akun Nessie Judge. Dari gambar di atas akun Nessie Judge, terjadi kepadatan informasi atau koneksi dengan beberpa akun yang menunjukan kedekatan dan adanya interaksi antara akun Nessie Judge dengan akun-akun lainnya yang berwarna hijau tosca. Jika diperbesar maka terlihat gambar di bawah ini.

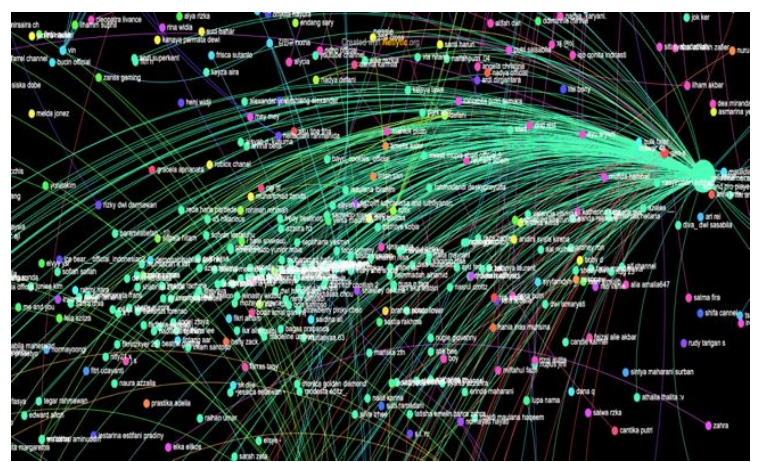

Gambar 4: Data Chain Network Akun Nessie Judge (Sumber: Data peneliti)

Namun jika dilihat secara keseluruhan ternyata indegree dalam konten tersebut tidak hanya akun Nessie Judge. Tetapi juga ada beberapa akun yang memiliki kepadatan dan sentralisasi informasi dari konten tersebut seperti akun sebagai berikut:

1) Akun cerita total indegree 88 akun, artinya terdapat 88 akun yang meberikan respon dari tanggapan akun cerita. Walaupun respon tersebut tidak berkaitan dengan konten YouTube Nessie Judge edisi Annoying Questions Pas Lebaran!. Ditunjukan dengan warna merah muda.

2) Akun btsismyinsfires total indegree 25 akun, artinya terdapat 25 akun yang memberikan respon kepada akun btsismyinsfires. Ditunjukan dengan warna kuning. 
Untuk lebih detail lagi peneliti mengambil satu contoh akun cerita untuk melihat indegree dan outdegree. Berikut ini adalah gambar indegree berupa garis merah mudah yang mengarah kepada aku cerita disebelah kira. Disebalah kanan adalah akun nashita $\mathrm{kr}$ sebagai outdegree yang memberikan respon pada akun cerita.
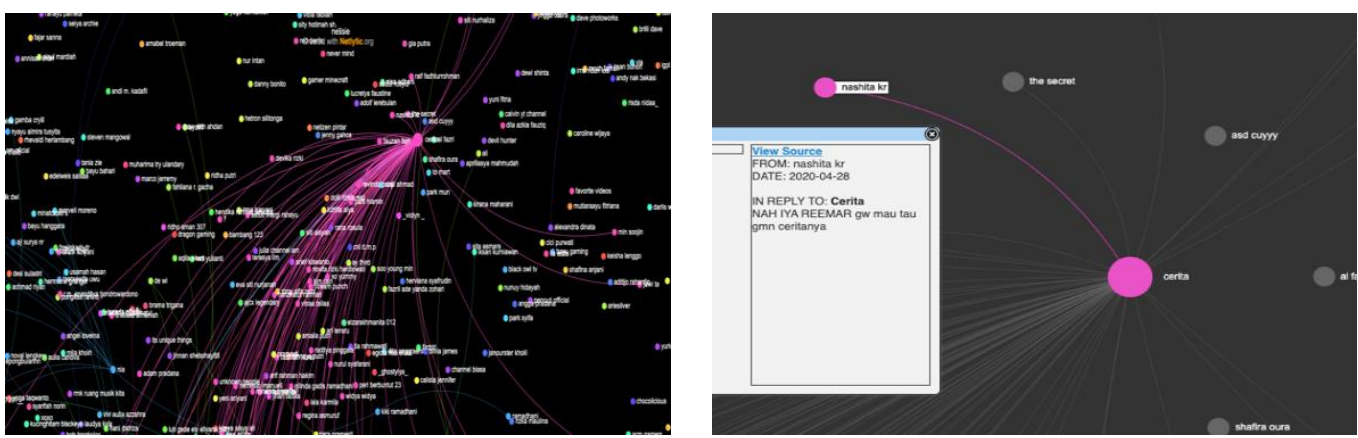

Gambar 5: Indegree dan Outdegree Akun Cerita (Sumber: Data peneliti)

Berikut ini adalah data Jaringan SNA akun YouTube Nessie Judge dalam konten Annoying Questions Pas Lebaran! Yang meliputi Centralization, density, Reciprocity, Modularity, dan diameter.

Tabel 2: Jaringan akun YouTube Nessie Judge dalam konten Annoying Questions Pas Lebaran!

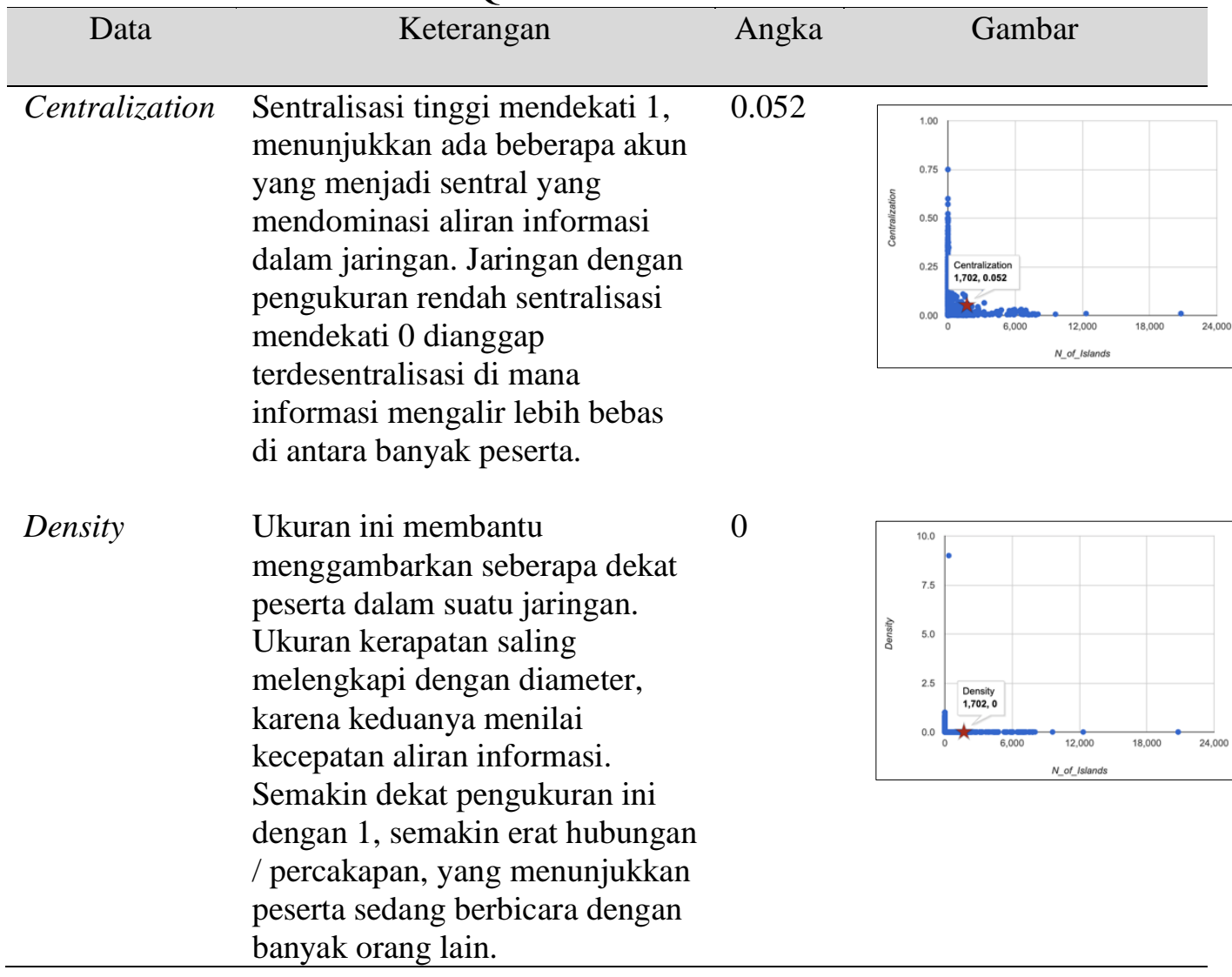


Sinta Paramita dan Lydia Irena: Retorika Digital dan Social Network Analysis Generasi Milenial Tionghoa melalui YouTube

\begin{tabular}{|c|c|c|c|}
\hline Data & Keterangan & Angka & Gambar \\
\hline Reciprocity & $\begin{array}{l}\text { Nilai yang lebih tinggi } \\
\text { menunjukkan banyak peserta } \\
\text { memiliki percakapan dua arah, } \\
\text { sedangkan nilai timbal balik } \\
\text { yang rendah menunjukkan } \\
\text { banyak percakapan satu sisi, } \\
\text { sehingga ada sedikit percakapan } \\
\text { bolak-balik. }\end{array}$ & 0 & $\sum_{0.000}^{0.00}$ \\
\hline Modularity & $\begin{array}{l}\text { Modularitas. Untuk memahami } \\
\text { modularitas, pertama-tama perlu } \\
\text { memahami konsep kluster dalam } \\
\text { visualisasi jaringan. Kluster } \\
\text { adalah sekelompok node yang } \\
\text { terhubung erat yang lebih } \\
\text { mungkin untuk berkomunikasi } \\
\text { satu sama lain daripada node di } \\
\text { luar Kluster. Modularitas, } \\
\text { membantu menentukan apakah } \\
\text { Kluster yang ditemukan mewakili } \\
\text { komunitas yang berbeda dalam } \\
\text { jaringan. Nilai modularitas yang } \\
\text { lebih tinggi menunjukkan } \\
\text { perpecahan yang jelas antara } \\
\text { komunitas yang diwakili oleh } \\
\text { Kluster di Netlytic. Nilai } \\
\text { modularitas yang rendah, } \\
\text { biasanya kurang dari 0.5, } \\
\text { menunjukkan bahwa Kluster, } \\
\text { yang ditemukan oleh Netlytic. }\end{array}$ & 0.763 & 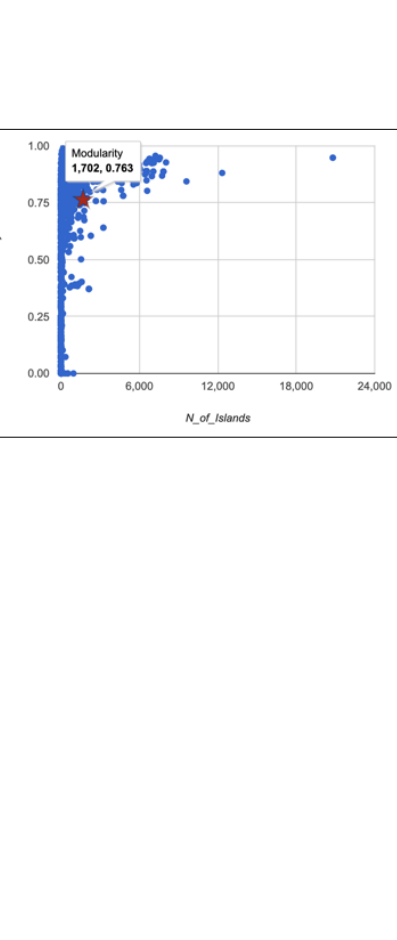 \\
\hline Diameter & $\begin{array}{l}\text { Diameter menghitung jarak } \\
\text { terpanjang antara dua peserta } \\
\text { jaringan. Ukuran ini } \\
\text { menunjukkan ukuran jaringan, } \\
\text { dengan menghitung jumlah node } \\
\text { yang diperlukan untuk berpindah } \\
\text { dari satu sisi ke sisi lainnya. }\end{array}$ & 4 & (20) \\
\hline
\end{tabular}

Berikut ini adalah penjelasan dari table analisis SNA akun YouTube Nessie Judge dalam konten Annoying Questions Pas Lebaran!:

1. Centralization. Nilai sentralisasi tinggi ditunjukan dengan angka 0.052, mendekati 1 diartikan sebagai adanya dominasi diantara pengguna di dalam konten tersebut tercatat terdapat tiga akun dominan yang menjadi sumber komunikasi. Tiga akun tersebut adalah akun cerita, putri, dan btsismyinsfires 
2. Density. Nilai density rendah ditunjukan dengan angka 0. Nilai tersebut menggambarkan tidak ada kedekatan atau hubungan antara pengguna di dalam semua konten tersebut.

3. Reciprocity. Nilai reciprocity atau timbal balik dalam sebuah konten menunjukan angka 0 . Nilai tersebut dapat diartikan sebagai tidak adanya komunikasi dua atau atau timbal balik antara pengguna. Atau menunjukan banyak percakapan satu sisi, sehingga hanya sedikt percakapan dua arah.

4. Modularity. Nilai modulariy menunjukan angka 0.763. Nilai tersebut diartikan sebagai adanya komunitas di dalam sebuah konten. Nilai modularity rendah jika angkarnya kurang dari 0.5. namun data analisis SNA menunjukan bahwa konten tersebut memiliki nilai modularity tinggi.

5. Diameter. Nilai diameter menunjukan angka 4, diartikan sebagai jarak terpanjang antara user ditunjukan dengan angka tersebut. Atau bisa dikatakan

Berdasarkan data name network/who mentions whom konten Annoying Questions Pas Lebaran!. Data name network/who mentions whom merupakan jaringan akun atau nama dalam jaringan komunikasi dalam membangun pesan. Untuk menemukan ikatan antara akun dalam sebuah jaringan oleh pengguna YouTube dapat dilihat dari adanya penulisan nama akun atau nama terkenal di YouTube dalam setiap komen-komen yang di unggahan. Data ini akan membentuk keterikatan antara akun satu dengan akun yang lain dalam sebuah jaringan. Berikut ini adalah data akun yang paling banyak posting atau komen dalam konten Annoying Questions Pas Lebaran!, dan daftar kata-kata yang paling sering digunakan oleh semua akun dalam konten tersebut. Dari gambar di bawah terlihat terdapat tiga akun dengan skor $12.5 \%$ akun terbanyak yang posting dalam konten tersebut. Ketiga konten tersebut adalah akun Farrel Channel diwakili warna biru , akun Elang 273 diwakili warna merah, dan akun Bambang 123 di wakili warna oranye. Sedangkan kata yang paling banyak digunakan seluruh pengguna akun dalam konten tersebut adalah kata "nessie, dalgona, bahasa, bikin" dan lain-lain. Berikut ini adalah gambar ilustrasinya:

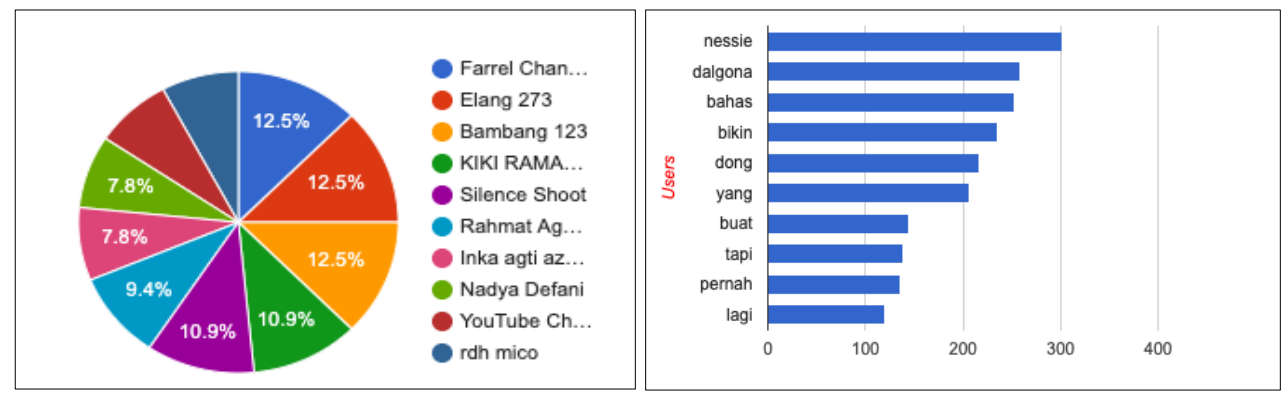

Gambar 7: Data Akun dan Kata Yang Paling Banyak Posting (Sumber: Data peneliti) 


\section{Retorika Digital YouTube}

Berdasarkan data Social Netwok Analysis (SNA) YouTube di atas menunjukan konten yang diciptakan akun Nessie Judge memiliki keunikan khusus, terutama pada konten Annoying Questions Pas Lebaran!, Untuk membuat konten yang menarik YouTuber menggunakan kreatifitasnya untuk membuat konten menjadi menarik dan ramai diperbincangkan.

Influencer dan YouTuber asal Surakarta yang bernama Nasreen Anisputri Judge, atau lebih dikenal sebagai Nessie Judge. Nessie telah membuat akun YouTube-nya sejak tahun 2012 dan melalui akun tersebut Ia mengunggah vlog dimana Ia berbagi cerita dan juga mengangkat sebuah pembahasan tentang hal yang sedang viral atau menarik baginya. Hingga saat ini pengikut akun YouTube Nessie sudah mencapai lebih dari 1.000.000 orang dan video-videonya telah ditonton lebih dari 100 juta kali.

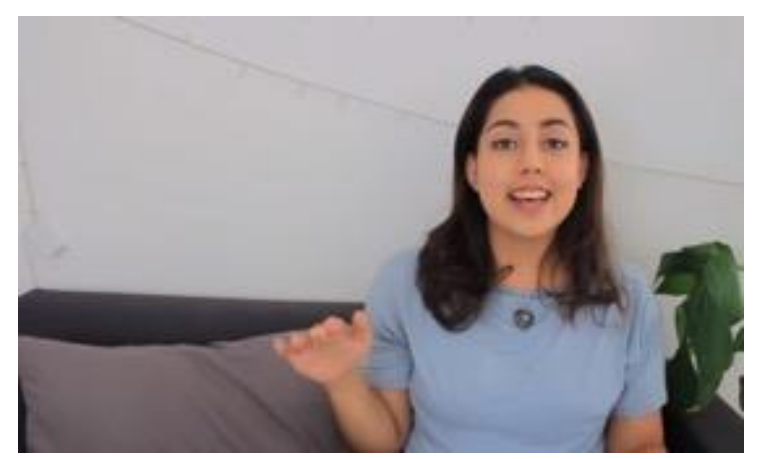

Gambar 8: Nessie Judge Vlog (Sumber: Instagram)

Pada mulanya Nessie membagikan konten tentang kesehariannya saat Ia masih tinggal di Eropa, serta konten-konten lain tentang Indonesia yang mewawancarai orang asing apakah mereka mengetahui Indonesia atau tidak. Nessie pun mulai menarik banyak perhatian khalayak dengan video yang berjudul "Where is Indonesia" dan "Indonesian Accent Challenge", dimana kedua video tersebut memperoleh lebih dari 200,000 viewers dalam waktu yang cukup singkat. Kemudian seiring berjalannya waktu konten Nessie mulai mengangkat topik seperti anti-bullying, LGBT, sexual consent, dan catcalling, hingga pada pertengahan tahun 2017 Nessie membuat segmen baru yang sampai sekarang membuat namanya semakin dikenal audiens. Konten tersebut adalah \#NERROR dengan kepanjangan Nessie Horror, dimana Ia mengunggah video yang berisikan hal-hal horor dan misteri. Konten ini merupakan konten yang paling diminati oleh khalayak Nessie, berkaca dengan banyaknya viewers pada setiap video \#NERROR dibandingkan video karya Nessie yang lain. 


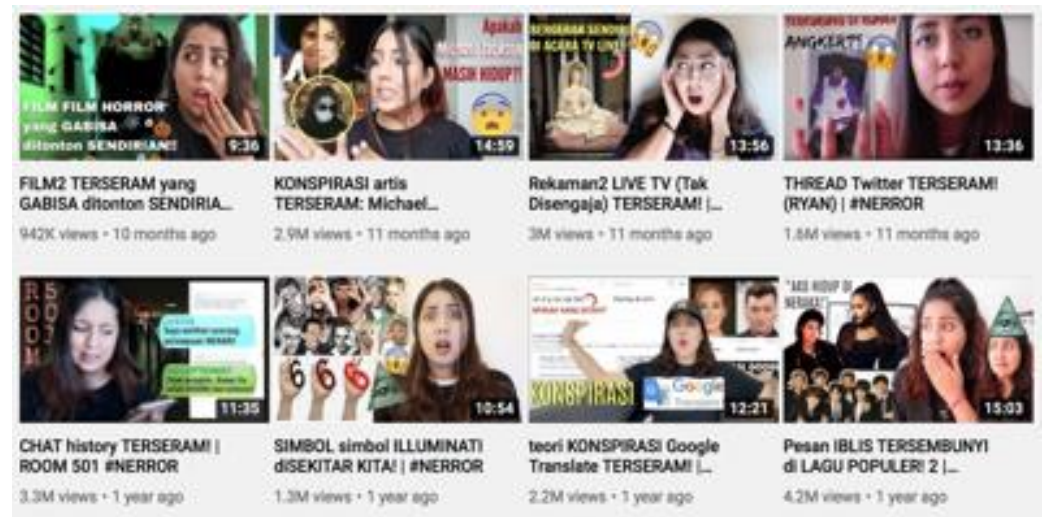

Gambar 9: Konten Retorika Nessie Judge Vlog (Sumber: YouTube)

Beberapa lain seperti video \#NERROR antara lain adalah KKN Desa Penari, Teori Terseram Kapal Titanic, Cerita-Cerita Ojek Online Terseram, Sekolah Terangker di Indonesia, Website Terseram di Dunia, Museum Ter-creepy di Dunia, Hantu-Hantu Terseram di Dunia, Teori-Teori Konspirasi Kartun Terseram, Permainan-Permainan Pemanggil Setan Terseram, dan masih banyak lagi. Menjadi konten andalan dari akun tersebut. Dalam retorika yang Nessie lakukan, Nessie kerap menggunakan bukti retoris logos dimana Ia banyak menunjukkan bukti fisik berupa foto pada videonya. Selanjutnya adalah bukti pathos berupa perasaan takut yang muncul setiap kali khalayak mendengar dan menyaksikan retorika yang dilakukan oleh Nessie, hal ini didukung dengan musik seram, intonasi suara, dan dinamika dari retorika Nessie.

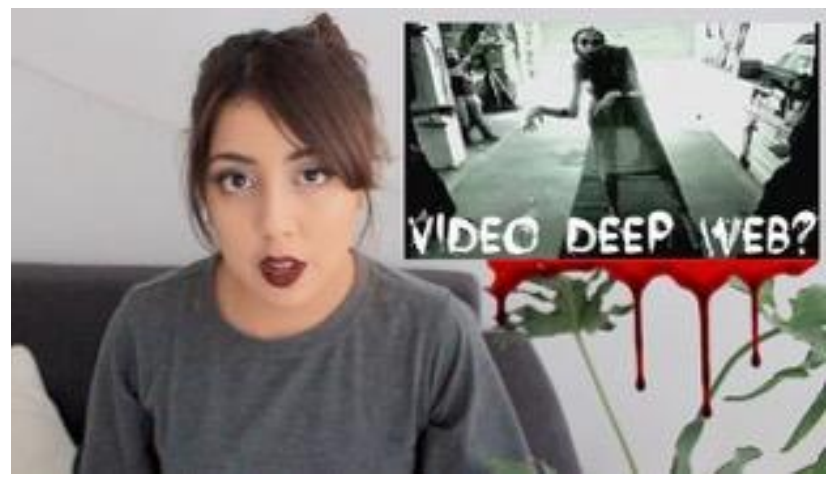

Gambar 10: Kanon Penciptaan dalam Retorika Nessie (Sumber: YouTube)

Retorika yang dilakukan oleh Nessie pada umumnya bertipe deliberatif, dimana retorika Nessie disusun sedemikian rupa hingga menentukan aksi yang akan dilakukan oleh khalayak setelah terpapar oleh retorika Nessie. Kanon retorika yang digunakan adalah penciptaan, pengaturan, gaya, dan penyampaian. Seperti yang telah disebutkan sebelumnya bahwa Nessie kerap memberikan bukti berupa foto penampakan dalam retorika digitalnya. Nessie juga menyusun retorikanya dengan dinamika cerita yang baik, serta gaya bahasa dan cara penyampaian yang ditata sedemikian rupa. Sejalan dengan yang digagaskan oleh Littlejohn (2002), komunikator membangun strategi dan sering menggunakan pendekatan yang umum untuk menggerakan khalayak. Teori retorika memahami bahwa kata-kata memiliki 
kekuatan, informasi itu berguna dalam membentuk penilaian, dan komunikasi dapat dievaluasi dan dikembangkan. Menantang pandangan lain yang menyatakan bahwa kata-kata bukanlah aksi, apa yang ditampilkan bukanlah kenyataan, gaya bukanlah substansi, dan opini bukanlah kenyataan.

Tabel 3: Retorika Digital YouTuber Nessie Judge

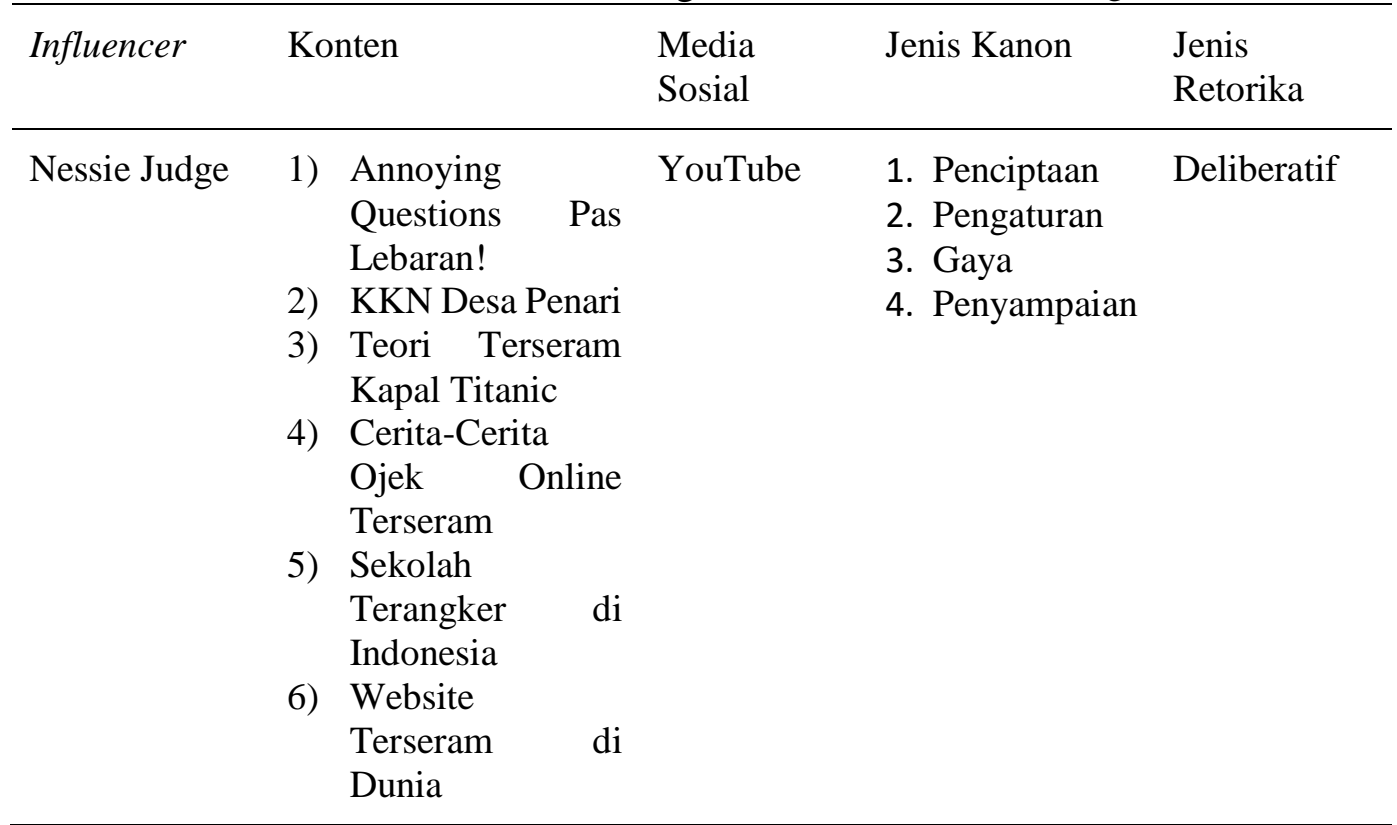

Hal ini didukung dengan olah data Social Netwok Analysis (SNA) YouTube. Konten dengan kekuatan deliberatif dapat menarik perhatian audiens. Tidak hanya sampai disitu beberapa akun juga terlibat dan menjadi opinion leader dalam konten tersebut dan membuat jaringan-jaringan khusus yang membuat beberapa akun saling berkaitan. Jika dicermati produksi konten dan kekuatan jaringan dalam media sosial menjadi kunci dalam pengembangan bisnis digital, dengan rekomendasi yang disampaikan influencer melalui YouTube produk-produk yang disampaikan masuk melalui perbincangan sederhana di dalam komen-komen YouTube. Penelitian ini memang belum mengulas lebih mendalam terkait kunci keberhasilan pengembangan bisnis digital pada generasi milenial saat ini. Namun untuk tahap awal penelitian ini berusaha memaparkan jaringan komunikasi yang terbentuk dari sebuah konten. Pada penelitian selanjutnya penelitian ini akan mengulas lebih dalam terkait teks-teks yang menjadi kata kunci dari keberhasilan dalam bisnis digital khususnya dikalangan milenial.

\section{Simpulan}

Melalui retorika digital, generasi melenial dapat berkolaborasi, berinovasi, dan membagikan nilai yang bersifat arif, sejalan dengan norma dan identitas mereka. Berbagai kanon retorika digunakan oleh objek penelitian yaitu penciptaan, pengaturan, gaya, penyampaian, dan ingatan, serta retorika deliberatif. Dalam teori retorika, komunikator seperti pembicara, produser media, dan penulis melihat 
masalah atau tantangan sebagai kebutuhan yang harus dihadapi dengan pesan yang disusun sedemikian rupa.

Hal tersebut terbukti dari analisis SNA yang memaparkan interaksi yang terjadi di dalam konten tersebut menunjukan adanya beberapa audiens yang menjadi sentral dominan dalam konten tersebut yang ditunjukan dengan angka 0.052 mendekat 1 yang dapat diartikan sentralisasi tinggi. Dominasi tersebut ditunjukan salah satunya oleh akun cerita dan akun btsismyinsfires. Untuk nilai density yang mengukur kedekatan antara peserta atau audiens di dalam jaringan konten tersebut menunjukan angka 0 , dapat diartikan tidak ada kedekatan antara audiens di dalam konten. Nilai reciprocity juga serupa dari hasil analisis SNA menunjukan angka 0 , dapat diartikan tidak adapercakapan dua arah atau hubungan timbal balik diantara pengguna. Sejalan dengan komponen sentralisasi yang menunjukan terdapat beberapa konten yang dominan, data modularitas menunjukan hal yang serupa dengan anka 0,763 , dapat diartikan sebagai terdapat pola komunitas di dalam sebuah konten yang digambarkan dengan garis sewarna yang rumit atau edges antara peserta audiens atau node. Terakhir adalah nilai diameter yang menunjukan hasil 4, dapat diartikan bahwa ukuran jaringan yang diperlukan antar node untuk berpindah dari satu sisi ke sisi lainnya. atau aliran informasi rendah.

\section{Ucapan Terima Kasih}

Ucapan terima kasih diberikan kepada Kemenristekdikti yang memberikan kesempatan kepada peneliti khususnya bidang ilmu komunikasi untuk mengembangan ilmu pengetahuan dan Universitas Tarumanagara yang dukungan atas terselenggaranya penelitian ini. Serta Fakultas Ilmu Komunikasi Universitas Tarumanagara sebagai tempat berkembangnya ide-ide ilmu pengetahuan dalam bidang Ilmu Komunikasi.

\section{Daftar Pustaka}

APJII, A. J. P. I. I. (2017). Infografis Penetrasi \& Perilaku Pengguna Internet Indonesia. Teknopreuner, 1(Hasil Survei Penetrasi dan Perilaku Pengguna Internet Indonesia 2017), 1-39.

Bratawisnu, K. M., \& Alamsyah, A. (2018). Social Network Analysis Untuk Analisa Interaksi User Dimedia Sosial Mengenai Bisnis E-commerce (Studi Kasus: Lazada, Tokopedia Dan Elevenia). JURNAL MANAJEMEN DAN BISNIS (ALMANA) VOL., 2(2), 107-115. Retrieved from http://journal.unla.ac.id/index.php/almana/article/view/143

Budiman, H. (2018). Pemanfaatan Retorika Dalam Bidang Ekonomi Pada Proses Transaksi Jual Beli Ikan Di Pasar Keppo. Jurnal Komposisi, 1(1), 11-20. Retrieved from http://ejournal.unira.ac.id/index.php/jurnal_komposisi/article/view/368

Dendy, K., Iriani, A., \& Manongga, D. (2020). PEMANFAATAN SOCIAL NETWORK ANALYSIS (SNA) UNTUK MENGANALISIS KOLABORASI KARYAWAN PADA PT. ARUM MANDIRI GROUP | Kurniawan | Jurnal Transformatika. TRANSFORMATIKA, 17, 149-159. 
https://doi.org/http://dx.doi.org/10.26623/transformatika.v17i2.1646

Eriyanto. (2014). Analisis Jaringan Komunikasi. Perpustakaan Nasional : Katalog Dalam Terbitan (KDT). https://doi.org/10.1017/CBO9781107415324.004

Faisal, M. (2018). Gernerasi Phi Memahami Milenial Mengubah Indonesia. Jakarta: Republika Penerbit.

GetCRAFT. (2018). Indonesia Native Advertising And Influencer Marketing Report 2018. Retrieved from https://academy.getcraft.com/hubfs/Whitepaper File/2018/GetCRAFT Indonesia Native Advertising \& Influencer Marketing Report 2018.pdf

Gruzd, A., \& Haythornthwaite, C. (2013). Enabling Community Through Social Media. JOURNAL OF MEDICAL INTERNET RESEARCH, 15(10). https://doi.org/10.2196/jmir.2796

Latupeirissa, A., Sediyono, E., \& Iriani, A. (2019). Pemanfaatan Social Network Analysis Untuk Menganalisis Kolaborasi Komunikasi Pada Balai Perikanan Budidaya Laut Ambon. JURNAL SISTEM INFORMASI BISNIS, 9(2), 121. https://doi.org/10.21456/vol9iss2pp121-132

Littlejohn, S. W. (2002). Theories of Human Communication (edisi ketujuh). Belmont: Thomson Learning.

Moriansyah, L. (2015). Pemasaran Melalui Media Sosial: Antecedents Dan Consequences. Jurnal Penelitian Komunikasi Dan Opini Publik, 19(3), 187-196. https://doi.org/http://dx.doi.org/10.33299/jpkop.19.3.346

Netlytic. (2020). SNA measures plot. Retrieved May 27, 2020, from https://netlytic.org/network/sna/snachart.php?datatype=email $1 \&$ datatype $=$ email1\&net_centralization $=0.05241 \&$ net_density $=0.0001077 \&$ net_recipro city $=0 \& n e t \_m o d u l a r i t y=0.7633 \& n e t \_i s l a n d s=1702 \& n e t \_d i a m e t e r=4 \& n e t$ _nodes $=2231 \&$ net_edges $=536$

Pelly, U. (2018). Akar Kerusuhan Etnis di Indonesia : Suatu Kajian Awal Konflik dan Disintegrasi Nasional di Era Reformasi. Antropologi Indonesia. https://doi.org/10.7454/ai.v0i58.3363

Prabowo, T. L., \& Irwansyah, I. (2018). Media Komunikasi Digital PolisiKu: Pelayanan Publik Polri kepada Masyarakat. Jurnal Studi Komunikasi (Indonesian Journal of Communications Studies), 2(3), 382. https://doi.org/10.25139/jsk.v2i3.1174

Prasetiantono, A. T. (2018). Revolusi Industri 4.0 - Pusat Studi Ekonomi Dan Kebijakan Publik. Retrieved February 6, 2020, from https://psekp.ugm.ac.id/2018/04/10/revolusi-industri-4-0/

Pratama, I. B., \& Ulfa, A. A. I. (2017). DISCOURSE NETWORKING ANALYSIS SEBAGAI METODE PENELITIAN ALTERNATIF DALAM KAJIAN ILMU KOMUNIKASI DISCOURSE. Jurnal Penelitian Komunikasi Dan Opini Publik, 21(2), 126-136. https://doi.org/http://dx.doi.org/10.33299/jpkop.21.2.1129

Richard, W., \& Turner, H. L. (2017). Pengantar Teori Komunikasi Analisis dan Aplikasi. Jakarta: Penerbit Salemba Humanika.

Saleh, G.-, \& Pitriani, R. (2018). Pengaruh Media Sosial Instagram dan WhatsApp Terhadap Pembentukan Budaya "Alone Together." Jurnal Komunikasi, 10(2), 103. https://doi.org/10.24912/jk.v10i2.2673 
Tapscott, D. (2013). Grown Up Digital Yang Muda Yang Menggubah Dunia. Jakarta: PT Kompas Gramedia Pustaka Utama.

Zaenudin, A. (2018). Influencer di Media Sosial, Penantang Tangguh Iklan Konvensional. Retrieved February 6, 2020, from https://tirto.id/influencerdi-media-sosial-penantang-tangguh-iklan-konvensional-cEfr 